\title{
Analisis Kemampuan Koneksi Matematis Terhadap Model Pembelajaran MASTER (Motivating, Acquiring, Searching, Triggering, Exhibiting, Reflecting), dan Self Efficacy
}

\author{
Naziah Ulvah Ardiani, Achmad Asrori, Sri Purwanti Nasution \\ Universitas Islam Negeri Raden Intan Lampung \\ *naziahulfaardiani@gmail.com ${ }^{1}$
}

\begin{abstract}
ABSTRAK
Tujuan dari penelitian ini yaitu untuk mengetahui pengaruh model pembelajaran MASTER terhadap kemampuan koneksi matematis peserta didik ditinjau dari self efficacy. Metode yang digunakan dalam penelitian ini adalah Quasy Experimental Design dengan desain faktorial 2x3. Populasi penelitian ini adalah seluruh peserta didik kelas VIII SMPN 1 Belitang Jaya. Sampel yang diambil sebanyak 2 kelas yaitu kelas eksperimen dan kelas kontrol. Kelas eksperimen diberikan perlakuan model pembelajaran MASTER, sedangkan kelas kontrol diberikan perlakuan model konvesional. Penelitian ini menggunakan teknik analisis data uji Anova dua jalan. Berdasarkan hasil analisis dan perhitungan diperoleh hasil dengan kesimpulan: (1) terdapat pengaruh model pembelajaran MASTER terhadap kemampuan koneksi matematis, (2) terdapat pengaruh self efficacy terhadap kemampuan koneksi matematis peserta didik, (3) tidak terdapat interaksi antara perlakuan model pembelajaran dan kategori self efficacy terhadap kemampuan koneksi matematis peserta didik
\end{abstract}

Kata Kunci: Model MASTER, self efficacy, dan Koneksi Matematis

\section{ABSTRACT}

The purpose of this study was to determine the effect of the MASTER learning model on students' mathematical connection abilities in terms of self-efficacy. The method used in this research is Quasy Experimental Design with $2 x 3$ factorial design. The population of this study were all students of class VIII SMPN 1 Belitang Jaya. The samples taken were 2 classes, namely the experimental class and the control class. The experimental class was given the MASTER learning model treatment, while the control class was given the conventional model treatment. This study uses a two-way Anova test data analysis technique. Based on the results of the analysis and calculations obtained, the hypotheses are (1) There is an effect of the MASTER learning model on the ability of mathematical connections. (2) There is an influence of self efficacy on the students' mathematical connection ability. (3) There is no interaction between the treatment of the learning model and the self-efficacy category on the students' mathematical connection abilities

Keywords: MASTER Model, self efficacy, and Mathematical Connection 


\section{PENDAHULUAN}

Matematika berasal dari bahasa Yunani mathematike yang berarti mempelajari, kata tersebut mempunyai asal kata mathema yang berarti pengetahuan atau ilmu (knowledge, science) (Negara, 2014). Matematika yaitu ilmu pengetahuan yang sifatnya universal, matematika sangat penting karena memiliki peranan dalam memajukan daya pikir manusia. Prosedur dalam pembelajaran matematika tidak terlepas dari angka maupun simbol, lebih menekankan fungsi otak kiri yaitu analisis, logika, sistematis dan teratur. (Amin, 2016) Ilmu pengetahuan yang didapat dari berpikir yang menekankan pada rasio dari kehidupan seluruh manusia, dari yang kompleks maupun yang sederhana adalah matematika (Marliani, 2015) Peranan matematika sangatlah penting dan tidak dapat dibantah, baik dibidang ilmu pengetahuan dan teknologi, ataupun dalam dunia perekonomian. Matematika menjadi suatu mata pelajaran yang wajib disekolah, karenanya matematika sudah diajarkan kepada siswa usia dini hingga menengah hingga ke pendidikan tinggi (Syazali, 2015). Berdasarkan pendapat yang sudah dijabarkan di atas, dapat disimpulkan bahwa matematika adalah ilmu pengetahuan yang di dalamnya mempelajari berbagai macam perhitungan dengan menggunakan rumus dalam bentuk yang mudah sampai yang sulit, menggunakan penalaran yang mendalam dan berpikir secara logika.

Karakteristik dalam matematika adalah mempunyai objek tetapi abstrak. Keabstrakan itu yang bisa membuat peserta didik sulit dalam memahami semua konsep dan kesulitan dalam menyelesaikan persoalan, karena kebanyakan peserta didik mengandalkan hafalan yang ada dibuku (Maarif, 2015) sehingga tidak sedikit peserta didik yang cenderung takut dengan pelajaran matematika yang memiliki rumus-rumus dan perhitungan yang rumit.

Ketidaktertarikan atau kesulitan peserta didik terhadap pelajaran matematika tersebut ditunjukkan terhadap rendahnya hasil ulangan harian matematika di SMPN 1 Belitang Jaya yang dapat dilihat pada Tabel 1 .

\begin{tabular}{|c|c|c|c|c|}
\hline \multirow{2}{*}{ No } & \multirow{2}{*}{ Kelas } & \multicolumn{2}{|c|}{ Nilai Matematika Peserta Didik $(x)$} & \multirow{2}{*}{ Jumlah } \\
\hline & & $x<75$ & $x \geq 75$ & \\
\hline 1 & VIII 4 & 28 & 5 & 33 \\
\hline \multirow[t]{2}{*}{2} & VIII 5 & 25 & 7 & 32 \\
\hline & Jumlah & 53 & 12 & 65 \\
\hline
\end{tabular}

Terlihat pada Tabel 1 menunjukkan hasil belajar peserta didik yang masih rendah, hal ini bukan hanya bersumber dari peserta didik, tetapi dapat pula dipengaruhi dari pendidik itu sendiri. Rendahnya hasil belajar peserta didik juga sangat erat kaitannya dengan strategi pembelajaran yang dipakai oleh pendidik ketika mengajar. Proses pembelajaran di SMP N 1 Belitang Jaya masih memakai model pembelajaran konvensional dimana pendidik hanya berceramah dan menjelaskan semua materi. Peserta didik juga beranggapan bahwa kegiatan pembelajaran di kelas biasanya hanya monoton serta membosankan dan juga soal yang diberikan oleh guru berbeda dengan contoh soal yang dijelaskan, sehingga dirasa sulit untuk menyelesaikannya. Hal tersebut mengakibatkan siswa menjadi malas untuk belajar dan mengakibatkan rendahnya hasil belajar peserta didik. Memahami dan melihat permasalahan 
tersebut, perlu adanya pemilihan model pembelajaran yang tepat dalam pembelajaran yang dapat membuat peserta didik dengan mudah dalam memahami materi dan bersemangat dalam kegiatan pembelajaran. Model pembelajaran yang mungkin efektif adalah model pembelajaran MASTER.

Model pembelajaran MASTER merupakan cara belajar cepat yang dijadikan strategi pembelajaran. Model pembelajaran MASTER memiliki enam tahap pembelajaran yaitu: (1) Motivating your mind, (2) Acquiring the information, (3) Searching, (4) Triggering, (5) Exhibiting, dan (6) Reflecting (Rose et al., 2007) yang bertujuan agar suatu konsep dapat dipahami dengan cepat dan baik. Pembelajaran MASTER merupakan pembelajaran yang menginginkan peserta didik mengalami kesenangan dalam pelaksanaan pembelajaran (Safitri dkk., 2014). Penerapan model pembelajaran MASTER dapat memotivasi peserta didik dengan cara melakukan tanya jawab, sehingga peserta didik mencari makna yang dibimbing oleh pendidik untuk memicu memorinya. Selanjutnya pendidik memberi kesempatan kepada peserta didik untuk aktif dalam proses diskusi dan melaporkan hasil diskusinya. Pendidik dalam hal ini harus memberikan penguatan positif untuk merangsang kemampuan koneksi matematis sehingga keberhasilan peserta didik (Putri et al., 2013).

Kemampuan koneksi matematis merupakan bagian penting yang harus memperoleh penekanan pada setiap jenjang pendidikan. Koneksi matematis ialah keterkaitan antara topik matematika, matematika dengan disiplin ilmu lain dan matematika dalam kehidupan sehari-hari (Romli, 2016) (Yumiati, 2017). Sehingga dengan menguasai koneksi matematis dapat membantu peserta didik menjawab persoalan matematika yang dianggapnya rumit. Melalui proses koneksi matematis, konsep pemikiran dan wawasan peserta didik akan bertambah luas, tidak terfokus pada satu topik. Mampu mengambil keputusan secara masuk akal (reasonable), mendalam (in depth), dapat dipertanggungjawabkan (responsible) dan berdasarkan pemikiran yang cerdas (skillfull thinking) (Lestari, 2014).

Pendidik juga harus memperhatikan faktor internal dan eksternal untuk meningkatkan kemampuan koneksi matematis peserta didik. Faktor internal yang dimaksud misalnya self efficacy (keyakinan diri) dan faktor eksternal yang merupakan faktor yang berasal dari luar misalnya media pembelajaran, sarana prasarana, dan lain-lain (Musriliani et al., 2015). Self efficacy merupakan keyakinan akan kemampuan yang dimiliki yang mempengaruhi kemampuan peserta didik dalam menyelesaikan soal kemampuan koneksi ma tematis karena pada tiap diri individu memiliki 3 dimensi, di antaranya adalah dimensi tingkat (level), dimensi kekuatan (strength), dan dimensi generalisasi (generality) (Novianti et al., 2019). Peserta didik yang memiliki self efficacy yang baik akan berhasil dalam kegiatan belajarnya dan dapat melakukan tugas-tugas akademiknya dengan lancar. Berbeda jika self efficacy yang di miliki siswi rendah maka siswa akan cepat menyerah pada setiap permasalahan yang dihadapi (Yuliani, 2017).

Berdasarkan pemaparan tersebut di atas peneliti tertarik untuk melakukan penelitian dengan tujuan untuk mengetahui pengaruh model pembelajaran MASTER terhadap kemampuan koneksi matematis peserta didik ditinjau dari self efficacy. 


\section{METODE}

Penelitian ini memakai jenis eksperimen dengan penelitian Quasi Experimen Design. Quasi Experimen Design adalah penelitian yang memiliki kelompok kontrol tetapi tidak berfungsi sepenuhnya untuk mengontrol variabel-variabel luar yang mempengaruhi pelaksanaan eksperimen (Sugiono, 2013). peneliti mengambil dua kelas untuk diteliti, yaitu kelas eksperimen dan kelas kontrol. Kelas eksperimen ini dilaksanakan dengan perlakuan khusus yakni pada pembelajaran memakai model MASTER sedangkan kelas kontrol memakai model pembelajaran konvensional. Design penelitian ini adalah "posttest- only design" dengan rancangan faktorial $2 \times 3$. Desain penelitian disajikan dalam Tabel 2 .

Tabel 2. Desain Faktorial Penelitian

\begin{tabular}{cccc}
\hline & $B_{1}$ & $B_{2}$ & $B_{3}$ \\
\hline$A_{1}$ & $A_{1} B_{1}$ & $A_{1} B_{2}$ & $A_{1} B_{3}$ \\
$A_{2}$ & $A_{2} B_{1}$ & $A_{2} B_{2}$ & $A_{2} B_{3}$ \\
\hline
\end{tabular}

Keterangan:

$A_{1}=$ Metode Pembelajaran MASTER

$A_{2}=$ Metode Pembelajaran Konvensional

$B_{1}=$ Self Efficacy Tinggi

$B_{2}=$ Self Efficacy Sedang

$B_{3}=$ Self Efficacy Rendah

Objek pada penelitian ini yaitu model pembelajaran MASTER $\left(X_{1}\right)$ dan self efficacy $\left(X_{2}\right)$ sebagai variabel bebas, dan koneksi matematis $(Y)$ sebagai variabel terikatnya, dengan teknik pengumpulan datanya menggunakan tes dan angkat. Tes yang digunakan berupa soal kemampuan koneksi matematis sedangkan angket berupa pernyataan untuk melihat self efficacy peserta didik. Teknik analisis yang peneliti gunakan adalah uji normalitas, uji homogenitas, uji hipotesi anova dua jalan, dan uji komparasi ganda.

\section{HASIL DAN PEMBAHASAN}

Berdasarkan penelitian yang dilakukan peneliti, data penelitian diperoleh melalui tes koneksi matematis yang diberikan kepada peserta didik setelah pembelajaran. Data pengujian ditampilkan dan dijelaskan dalam Tabel 3. Pada Tabel 3, kelas eksperimen didapatkan nilai tertinggi $\left(x_{\max } x_{\max }\right) 100$, dan nilai terendah $\left(x_{\min } x_{\min }\right) 50$. Rataan pada kelas eksperimen adalah 80, dengan nilai tengah (median) 78 , nilai yang sering muncul (modus) 78, serta rentang nilai $(R)$ 50, dan simpangan baku 12,282. Kemudian, pada kelas kontrol nilai tertinggi $\left(x_{\max } x_{\max }\right)$ 94, dan nilai terendah $\left(x_{\min } x_{\min }\right) 50$. Rata-rata pada kelas kontrol adalah 71 , dengan nilai tengah (median) 69, nilai yang sering muncul (modus) 67, serta rentang nilai $(R)$ 44, dan simpangan baku 12,972. 
Tabel 3. Deskripsi Data Tes Kemampuan Koneksi Matematis

\begin{tabular}{cccccccc}
\hline \multirow{2}{*}{ Kelas } & \multirow{2}{*}{$\boldsymbol{x}_{\boldsymbol{m a x}}$} & $\mathrm{x}_{\min }$ & \multicolumn{3}{c}{ Ukuran Tendensi Sentral } & \multicolumn{2}{c}{ Ukuran Variansi Kelompok } \\
\cline { 5 - 8 } & & $\overline{\mathrm{x}}$ & $\mathbf{M e}$ & $\mathbf{M o}$ & $\mathbf{R}$ & $\mathbf{S}$ \\
\hline Eksperimen & 100 & 50 & 80 & 78 & 78 & 50 & 12,282 \\
Kontrol & 94 & 50 & 71 & 69 & 67 & 44 & 12,972 \\
\hline
\end{tabular}

Tabel 4. Deskripsi Data Angket Self Efficacy

\begin{tabular}{cccccc}
\hline \multirow{2}{*}{ Kelas } & $\overline{\boldsymbol{X}}$ & $\mathbf{S}$ & \multicolumn{3}{c}{ Kriteria Self Efficacy } \\
\cline { 4 - 6 } & & & Tinggi & Sedang & Rendah \\
\hline Eksperimen & 73,473 & 8,923 & 5 & 21 & 6 \\
Kontrol & 69,851 & 11,048 & 4 & 22 & 6 \\
\hline
\end{tabular}

Data amatan pada Tabel 4 pada kelas eksperimen diperoleh rataan nilainya yaitu 73,473 dan simpangan baku yaitu 8,923 serta diperoleh kategori self efficacy tinggi terdapat 5 peserta didik, kategori self efficacy sedang terdapat 21 peserta didik dan kategori self efficacy rendah terdapat 6 peserta didik. Sedangkan pada kelas kontrol diperoleh rataan nilainya yaitu 69,851 dan simpangan baku yaitu 11,048 serta diperoleh kategori self efficacy tinggi terdapat 4 peserta didik, kategori self efficacy sedang terdapat 22 peserta didik dan kategori self efficacy rendah terdapat 6 peserta didik.

Data tes yang telah diperoleh kemudian dianalisis untuk menjawab hipotesis penelitian. Hipotesis dalam penelitian ini adalah uji hipotesis anava dua jalan sel tak sama. Sebelum dilakukannya uji anova terlebih dahulu data tes tersebut diuji prasyaratkan yaitu melalui uji normalitas dan uji homogenitas. Kedua uji tersebut dijelaskan sebagai berikut.

\subsection{Uji Normalitas}

Uji normalitas yang digunakan adalah metode Lilifors pada data tes dan angket dengan taraf signifikan sebesar 5\%. Tabel 5 adalah tabel rangkuman uji normalitas. Uji analisis normalitas secara keseluruhan memperoleh nilai $L_{\text {hitu }} \mathrm{ng} \leq L_{\text {tabel }}$ yaitu $H_{0}$ diterima, sehingga peneliti menyimpulkan bahwa sampel mengikuti distribusi normal.

\begin{tabular}{lcc}
\multicolumn{3}{c}{ Tabel 5. Uji Normalitas } \\
\hline \multicolumn{1}{c}{ Kelas } & $\boldsymbol{L}_{\text {hitung }}$ & $\boldsymbol{L}_{\text {tabel }}$ \\
\hline Eksperimen & 0,091 & 0,150 \\
Kontrol & 0,126 & 0,150 \\
Self efficacy Tinggi & 0,149 & 0,271 \\
Self efficacy Sedang & 0,057 & 0,134 \\
Self efficacy Rendah & 0,118 & 0,242 \\
\hline
\end{tabular}

\subsection{Uji Homogenitas}

Uji yang dipakai yaitu uji Bartlett. Uji homogenitas dilaksanakan pada data tes dan angket menggunakan taraf signifikan 5\%. Tes dapat dikatakan homogen jika $x_{\text {hitu }}^{2} \leq x_{\text {tabel }}^{2}$. Hasil dari perhitungannya dapat dilihat pada Tabel 6. Berdasarkan Tabel 6 didapat bahwa untuk populasi model pembelajaran ( $\mathrm{x}_{\text {hitung }}^{2}<\mathrm{x}_{\text {tabel }}^{2}$ kelas eksperimen dan kontrol) mendapatkan nilai $x_{\text {hitu } n g}^{2}=0,097$ dengan $x_{\text {tabel }}^{2}=3,481$, sedangkan untuk kategori self efficacy (tinggi, 
sedang dan rendah) mendapatkan nilai $x_{\text {hitu }}^{2}=3,015$ dengan $x_{\text {tabel }}^{2}=5,591$. Keduanya memiliki $x_{\text {hitu ng }}^{2}$ lebih kecil dari $x_{\text {tabel }}^{2}$ dan tidak berada di daerah kritis, sehingga $\mathrm{H}_{0}$ untuk model pembelajaran dan Self Efficacy diterima. Jadi, dapat disimpulkan bahwa sampel tersebut berasal dari populasi yang homogen.

Tabel 6. Uji Homogenitas

\begin{tabular}{lccc}
\hline \multicolumn{1}{c}{ Homogenitas } & $\boldsymbol{x}_{\text {hitung }}^{\mathbf{2}}$ & $\boldsymbol{x}_{\text {tabel }}^{\mathbf{2}}$ & Keputusan Uji \\
\hline Kelas Eksperimen dan Kontrol & 0,097 & 3.481 & $\mathrm{H}_{0}$ diterima \\
Self Efficacy & 3,015 & 5,591 & $\mathrm{H}_{0}$ diterima \\
\hline
\end{tabular}

\subsection{Uji Hipotesis}

Setelah lulus uji prasyarat dengan perolehan sampel berasal dari populasi normal dan homogen, peneliti melakukan uji anova dua jalan. Hasil analisis dapat dilihat pada Tabel 7.

Tabel 7. Rangkuman Anova Dua Jalan

\begin{tabular}{ccccccc}
\hline Sumber & $\mathbf{J K}$ & $\mathbf{d K}$ & $\mathbf{R K}$ & $\boldsymbol{F}_{\text {hitung }}$ & $\boldsymbol{F}_{\text {tabel }}$ & Keputusan Uji \\
\hline Model (A) & 525.351 & 1 & 525.351 & 8.443 & 4.007 & $H_{0 A}$ ditolak \\
Self Efficacy (B) & 8298.161 & 2 & 4149.080 & 66.682 & 3.156 & $H_{0 B}$ ditolak \\
Interaksi (AB) & 56.081 & 2 & 28.040 & 0.451 & 3.156 & $H_{0 A B}$ diterima \\
Galat & 3608.880 & 58 & 62.222 & - & - & \\
Total & 12488.472 & 63 & - & - & - & \\
\hline
\end{tabular}

Tabel 7 menunjukkan hasil analisis yang dapat disimpulkan sebagai berikut.

a) $\quad F_{a}=8,443$ dengan taraf signifikansi 0,05 diperoleh $F_{(0,05 ; 1 ; 5 ~} \mathrm{g}=4.007$ yang berarti $F_{a}>F_{(0,05 ; 1 ; 5 \text { g }}$ maka $h_{0 A}$ ditolak sehingga dapat disimpulkan terdapat pengaruh model pembelajaran MASTER terhadap kemampuan koneksi matematis peserta didik.

b) $\quad F_{b}=66,682$ dengan taraf signifikansi 0,05 diperoleh $F_{(0,05 ; 2 ; 5 \&}=3,156$ sehingga $F_{b}>$ $F_{(0,05 ; 2 ; 5} g$ maka $H_{0 B}$ ditolak sehingga dapat disimpulkan terdapat pengaruh self efficacy yang tinggi, sedang, dan rendah terhadap kemampuan koneksi matematis peserta didik.

c) $\quad F_{a b}=0,451$ dengan taraf signifikansi 0,05 diperoleh $F_{(0,05 ; 5 ; 5 g}=3,156$ sehingga $F_{a b}<$ $F_{(0,05 ; 2 ; 5}{ }_{g} F_{b}>F_{(0,05 ; 2 ; 5}$ maka $H_{0 A B}$ diterima sehingga dapat disimpulkan tidak terdapat interaksi antara model pembelajaran MASTER dan self efficacy terhadap kemampuan koneksi matematis.

\subsection{Uji Komparasi Ganda}

Uji ini dilakukan untuk melihat perbedaan antar kelompok pada hipotesis penelitian yang ditolak yaitu $H_{0 A}$ dan $H_{0 B}$. Metode yang dipakai pada uji ini yaitu metode Scheffe. Berikut adalah rekapitulasi rerataan marginal.

Tabel 8. Rataan Marginal

\begin{tabular}{lcccc}
\hline \multirow{2}{*}{ Model Pembelajaran } & \multicolumn{3}{c}{ Self efficacy } & \multirow{2}{*}{ Rataan Marginal } \\
\cline { 2 - 4 } & Tinggi & Sedang & Rendah & \\
\hline MASTER & 95.556 & 80.952 & 62.963 & 79.824 \\
Konvensional & 91.667 & 71.717 & 54.630 & 72.671 \\
Rataan Marginal & 93.611 & 76.335 & 58.796 & \\
\hline
\end{tabular}


Hasil yang didapat berdasarkan Tabel 8 yaitu sebagai berikut.

a) Komparasi Ganda Antar Baris

Rataan marginal untuk perlakuan dengan menggunakan model pembelajaran MASTER adalah 79.824 dan rataan marginal perlakuan dengan menggunakan pembelajaran konvensional adalah 72,671, yang berarti bahwa 79,824 $>72,671$. Sehingga dapat disimpulkan bahwa model pembelajaran MASTER lebih baik dibandingkan model pembelajaran konvesional dalam mempengaruhi kemampuan koneksi matematis peserta didik.

b) Komparasi Ganda Antar Kolom

Berdasarkan rataan marginal pada Tabel 8 menunjukkan bahwa rataan marginal antar kolom dalam kategori self efficacy berbeda-beda. Komparasi ganda antar kolom perlu dilakukan karena pada kategori self efficacy terdapat 3 kelompok yaitu tinggi, sedang, dan rendah. Selanjutnya membandingkan menakah yang memiliki rataan yang berbeda perlu dilakukan uji komperasi ganda antar kolom. Tabel 9 menjelaskan rekapitulasi komparasi dari self efficacy tinggi, sedang dan rendah.

\begin{tabular}{ccccc}
\multicolumn{5}{c}{ Tabel 9. Perhitungan Uji Komparasi Ganda Antar Kolom } \\
\hline No & $\boldsymbol{H}_{\mathbf{0}}$ & $\boldsymbol{F}_{\text {hitung }}$ & $\boldsymbol{F}_{\text {tabel }}$ & Keputusan Uji \\
\hline 1 & $\mu_{1}$ vs $\mu_{2}$ & 41,157 & 6,312 & $H_{0}$ ditolak \\
2 & $\mu_{1}$ vs $\mu_{3}$ & 102,037 & 6,312 & $H_{0}$ ditolak \\
3 & $\mu_{2}$ vs $\mu_{3}$ & 39,347 & 6,312 & $H_{0}$ ditolak \\
\hline
\end{tabular}

Kesimpulan uji komparasi ganda antar kolom pada Tabel 9 sebagai berikut.

a) Perhitungan antara $\mu_{1} v s \mu_{2}$ diperoleh hasil $F_{\text {hitu ng }}=41,157$ dan $F_{\text {tabel }}=6,312$, maka dari perhitungan yang dilakukan tersebut bisa dilihat $F_{\text {hitu } n g}>F_{\text {tabel }}$ sehingga $\mathrm{H}_{0}$ ditolak, yang berarti terdapat pengaruh yang signifikan antara self efficacy yang tinggi dan self efficacy yang sedang terhadap kemampuan koneksi matematis. Terlihat juga pada Tabel 8 bahwa rataan marginal self efficacy tinggi, sebesar 93,611 dan lebih besar dibandingkan dengan rerata marginal self efficacy sedang yaitu sebesar 76,335. Dari hasil tersebut dapat disimpulkan bahwa peserta didik dalam kategori self efficacy tinggi lebih baik dari pada peserta didik dalam kategori self efficacy sedang terhadap kemampuan koneksi matematis.

b) Perhitungan antara $\mu_{1} v s \mu_{3}$ diperoleh hasil $F_{\text {hitu } n g}=102,037$ dan $F_{\text {tabel }}=6,312$, maka dari perhitungan yang dilakukan tersebut bisa dilihat hasil $F_{\text {hitu }} \mathrm{ng}>F_{\text {tabel }}$ maka $\mathrm{H}_{0}$ ditolak, yang berarti terdapat pengaruh yang signifikan antara self efficacy yang tinggi dan self efficacy yang rendah terhadap kemampuan koneksi matematis. Terlihat juga pada Tabel 8 bahwa rataan marginal self efficacy tinggi, sebesar 93,611 dan lebih besar dibandingkan dengan rerata marginal self efficacy rendah yaitu sebesar 58,796. Dari hasil tersebut dapat disimpulkan bahwa peserta didik dalam kategori self efficacy tinggi lebih baik dari pada peserta didik dalam kategori self efficacy rendah terhadap kemampuan koneksi matematis. 
c) Perhitungan antara $\mu_{2}$ vs $\mu_{3}$ diperoleh hasil $F_{\text {hitu } n g}=39,347$ dan $F_{\text {tabel }}=6,312$, maka dari perhitungan yang dilakukan tersebut bisa dilihat $F_{\text {hitu } n g}>F_{\text {tabel }}$ maka $\mathrm{H}_{0}$ ditolak, yang berarti terdapat pengaruh yang signifikan antara self efficacy yang sedang dan self efficacy yang rendah terhadap kemampuan koneksi matematis. Terlihat juga pada Tabel 8 bahwa rataan marginal self efficacy sedang, sebesar 76,335 dan lebih besar dibandingkan dengan rerata marginal self efficacy rendah yaitu sebesar 58,796. Dari hasil tersebut dapat disimpulkan bahwa peserta didik dalam kategori self efficacy sedang lebih baik dari pada peserta didik dalam kategori self efficacy rendah terhadap kemampuan koneksi matematis.

\section{SIMPULAN}

Berdasarkan hasil penelitian yang sudah dilakukan diperoleh kesimpulan sebagai berikut. (1) Terdapat pengaruh model pembelajaran MASTER terhadap kemampuan koneksi matematis peserta didik di SMPN 1 Belitang Jaya. Peserta didik dengan perlakuan menggunakan model pembelajaran MASTER memiliki kemampuan koneksi matematis yang lebih baik dibandingkan peserta didik dengan perlakuan menggunakan pembelajaran konvensional. (2) Terdapat pengaruh self efficacy terhadap kemampuan koneksi matematis peserta didik. Kemampuan koneksi matematis peserta didik dengan kategori self efficacy tinggi lebih baik dibandingkan peserta didik dengan kategori self efficacy sedang maupun rendah. Peserta didik dengan kategori self efficacy yang sedang mendapatkan kemampuan koneksi matematis yang lebih baik dibandingkan peserta didik dengan kategori self efficacy yang rendah. (3) Tidak terdapat interaksi antara perlakuan model pembelajaran dan kategori self efficacy terhadap kemampuan koneksi matematis peserta didik.

\section{DAFTAR PUSTAKA}

Amin, M. (2016). Pengaruh Mind Map dan Gaya Belajar terhadap Hasil Belajar Matematika Siswa. Tadris: Jurnal Keguruan Dan Ilmu Tarbiyah, 1(1), 85-92.

Lestari, K. E. (2014). Implementasi Brain-Based Learning Untuk Meningkatkan Kemampuan Koneksi dan Kemampuan Berpikir Kritis serta Motivasi Belajar Siswa SMP. Judika (Jurnal pendidikan UNSIKA), 2(1).

Maarif, S. (2015). Integrasi Matematika dan Islam dalam Pembelajaran Matematika. Infinity Journal, 4(2), 223-236.

Marliani, N. (2015). Peningkatan Kemampuan Berpikir Kreatif Matematis Siswa Melalui Model Pembelajaran Missouri Mathematics Project (MMP). Formatif: Jurnal Ilmiah Pendidikan MIPA, 5(1).

Musriliani, C., Marwan, M., \& Ansari, B. I. (2015). Pengaruh Pembelajaran Contextual Teaching Learning (CTL) terhadap Kemampuan Koneksi Matematis Siswa SMP Ditinjau dari Gender. Jurnal Didaktik Matematika, 2(2).

Negara, S. (2014). Hasan. Konsep Dasar Matematika Untuk PGSD. Aura Printing \& Publishing. 
Novianti, I., Darminto, B. P., \& Purwoko, R. Y. (2019). Penerapan Model Snowball Throwing Terhadap Pemecahan Masalah Ditinjau Dari Self Efficacy. Seminar Nasional Pendidikan Matematika Ahmad Dahlan, 6.

Putri, I. A. K., Pudjawan, K., \& Suditha, I. W. R. (2013). Pengaruh Model Pembelajaran Master terhadap Kemampuan Berpikir Kritis Siswa Kelas V SD 1 Banyuning Kecamatan Buleleng. MIMBAR PGSD Undiksha, 1(1).

Romli, M. (2016). Profil Koneksi Matematis Siswa Perempuan SMA dengan Kemampuan Matematika Tinggi dalam Menyelesaikan Masalah Matematika. JIPMat, 1(2).

Rose, C., \& Nicholl, M.J. 2007. Accelerated Learning for the 21st Century. Nuansa.

Safitri, N. M. D., Kristiantari, M. R., \& Abadi, I. B. G. S. (2014). Pengaruh Model Pembelajaran Master Berbantuan Media Cerita Rakyat Terhadap Keterampilan Membaca Siswa Pada Pelajaran Bahasa Indonesia Kelas V SDN 12 Padangsambian. MIMBAR PGSD Undiksha, 2(1).

Sugiono. (2013). Metode Penelitian Kuantitatif, Kualitatif dan RnD. Alfabeta.

Syazali, M. (2015). "Pengaruh Model Pembelajaran Creative Problem Solving Berbantuan Media Maole 11 Terhadap KemampuanPemecahan Masalah Matematis". Al-Jabar: Jurnal Pendidikan Matematika, 6(1), 91-98. https://doi.org/10.24042/ajpm.v6i1.58 